ACTA MYCOLOGICA

Vol. 42 (1): 93-98

2007
Dedicated to Professor Alina Skirgietto

on the occasion of her ninety-fifth birthday

\title{
New data on some rare species of Hyphomycetes from Lithuania
}

\author{
SVETLANA MARKOVSKAJA \\ Institute of Botany, Laboratory of Mycology \\ Žaliụjų ežerų 49, LT-2021 Vilnius, svetlana.m@botanika.lt
}

Markovskaja S.: New data on some rare species of Hyphomycetes from Lithuania. Acta Mycol. 42 (1): 93-98, 2007.

The paper presents new data on ecological peculiarities of five anamorphic fungi species, Cladorrhinum foecundissimum, Dwayaangam cornuta, Lateriramulosa uni-inflata, Pyramidospora herculiformis and Tetraploa setifera, their distribution and substrate preferences are discussed. Short description, illustration and map of localities in Lithuania of recorded species are presented.

Key words: anamorphic fungi, Hyphomycetes, diversity, ecology, distribution, Lithuania

\section{INTRODUCTION}

Anamorphic fungi inhabiting forest litter are characterized by wide adaptation abilities in different environments, but their species composition and ecology are still insufficiently known. The best-known and most studied are terrestrial, aquatic and aero-aquatic groups of Hyphomycetes (Ellis 1971, 1976; Matsush ima 1975; Ingold 1975; Bärlocher 1992 et al.).

During the studies of Hyphomycetes associated with forest litter in various terrestrial and freshwater ecosystems in mixed deciduous forests of central and southeast Lithuania in 1999-2004, five rare and interesting for their ecological adaptation patterns species were obtained both in terrestrial and aquatic habitats. Recorded species were mainly polytrophic and developed as saprobes on dead woody plant substrates. Till present time three reported here fungi species, Cladorrhinum foecundissimum, Lateriramulosa uni-inflata and Tetraploa setifera were known exceptionally as terrestrial or soil-inhabiting (Matsushima 1971; Mouchacca, Gams 1993; Révay 1993), other two, Dwayaangam cornuta and Pyramidospora herculiformis as aquatic (Descals, Webster 1982; Singh 1976). Our observation indicated that they can grow, sporulate and actively decompose plant debris of forest litter both in moist terrestrial and submerged conditions. Whereas these species are characterized by amphibious nature of development, it is best to place them into the specific and still 
poorly studied ecological group of "amphibious" fungi (Michaelides, Kendrick 1978; Bärlocher 1992; Dix, Webster 1995) and regard them as such.

Part of the reported here species are known only from few collections worldwide and our data supplement knowledge on their substratum specificity, habitats and geography.

\section{MATERIALS AND METHODS}

The specimens were collected directly from the terrestrial forest litter or were obtained by cultivating terrestrial litter in moist chamber in the laboratory. Submerged leaves were collected from aquatic habitats (forest streams, lakes, rivers) and later incubated in Petri dishes under the thin layer of distilled water. The fungi were studied using standard microscopic techniques and identified basing on their morphological properties and character of conidiogenesis. Descriptions and illustration were made from fresh preparations in distilled water. Specimens of dried material and permanent glass slides with lacto-phenol are deposited in the fungal collection at the Herbarium of the Institute of Botany (BILAS), Vilnius.

\section{DESCRIPTION AND DISCUSSION}

Cladorrhinum foecundissimum Sacc. \& Marchal, Bull. Soc. R. Bot. Belg., 24: 65, 1885. (Fig. 1 A).

Mycelium yellowish-grey with clusters of subhyaline, branched, 3-4 $\mu \mathrm{m}$ wide, vegetative hyphae. Conidiogenous cells integrated, intercalary, monophialidic, determinate. Phialides subhyaline, ampulliform or subspherical with distinct collarettes, 6.3-9 x 1.5-3.6 $\mu \mathrm{m}$. Conidia subhyaline or hyaline, smooth-walled, dacryoid or obclavate, 2.5-2.7 $\mu \mathrm{m}$ in diameter, aggregated in slimy masses.

MATERIAL EXAMINED: on decaying unidentified wood, moist forest litter, Kèdainiai distr., Lančiūnava forest, September 21, 1999; on submerged unidentified wood, Lazdijai distr., Lake Ragožis, August 30, 2001.

Note: In Europe Cladorrhinum foecundissimum previously has been isolated mainly from soil (Arx, Gams 1966; Holubová-Jechová 1979; Borowska 1986; Mouchacca, Gams 1993). From submerged conditions it was noted for the first time by Hyde and Goh (1999) on unidentified wood in the U.K. In Lithuania it was collected both from terrestrial and submerged habitats. Accordingly this species could be placed into the group of "amphibious" fungi. This species is widely distributed in Northern Hemisphere, though uncommon.

Lateriramulosa uni-inflata Matsush., Microfungi of the Solomon Islands and Papua-New Guinea (Osaka): 34, 1971. (Fig. 1 B).

Mycelium hyaline. Conidiophores semi-micronematous, hyaline, up to $20 \mu \mathrm{m}$ long. Conidiogenous cells holoblastic, terminal, determinate, integrated. Conidia hyaline, composed of three indentate branches, 20-23 $\mu \mathrm{m}$ in diameter.

MATERIAL EXAMINED: on acorns of Quercus robur, moist forest litter, Vilnius environs, Verkiai Regional Park, November 3, 1999; on submerged leaves of Tilia cordata, Vilnius environs, Verkiai Regional Park, forest stream, November 12, 2001; on 

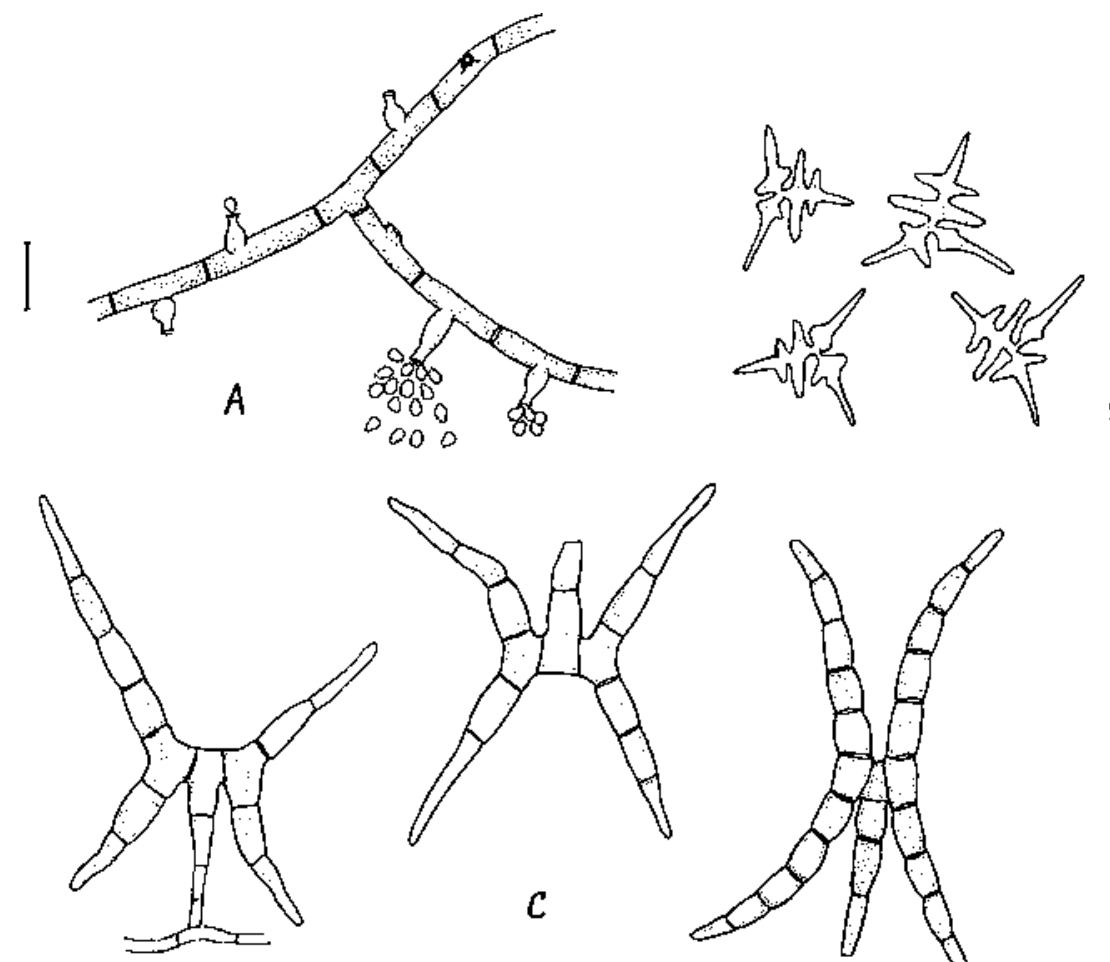

B
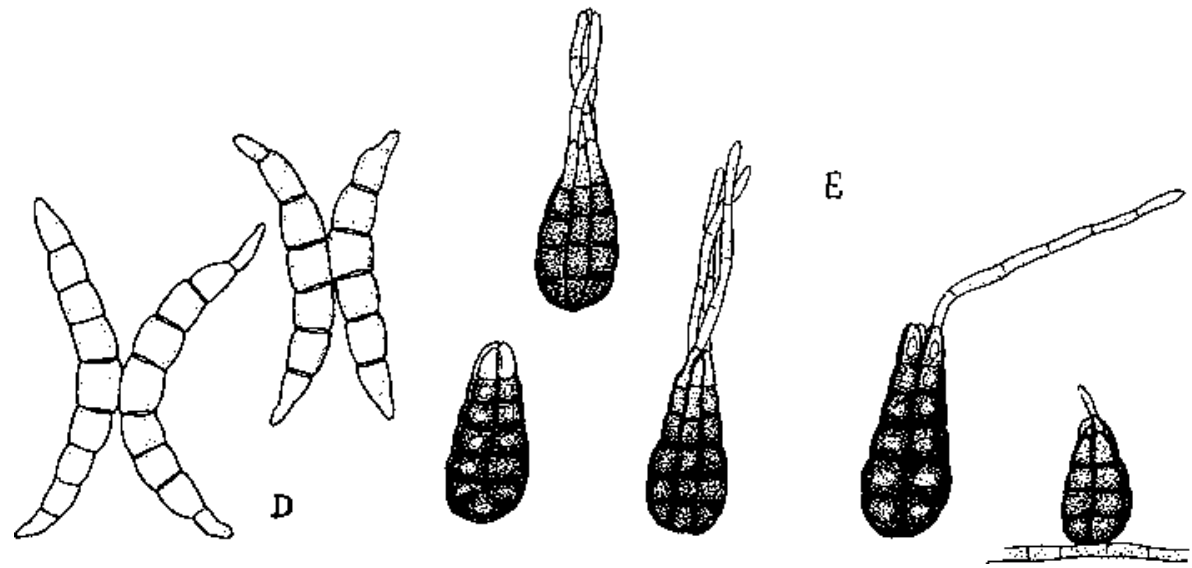

Fig. 1. A - hyphae with phialides and conidia of Cladorrhinum foecundissimum; B - conidia of Lateriramulosa uni-inflata; $\mathrm{C}$ - conidiophore with conidia of Dwayaangam cornuta; D - conidia of Pyramidospora herculiformis; E - conidia of Tetraploa setifera. Scale bars: $\mathrm{A}=10 \mu \mathrm{m} ; \mathrm{B}-\mathrm{E}=20 \mu \mathrm{m}$.

submerged leaves of Quercus robur, Vilnius environs, Verkiai Regional Park, river Neris, November 12, 2001.

Note: This species was described by Matsushima (1971) on decaying leaves as terrestrial fungus from Papua-New Guinea and later was also collected in Japan 
(Matsushima 1975). It is also known from North America (Crane 1968). In Europe it is rarely collected as waterborne from washed litter and foam (Marva nová 1973; Ingold 1975; Göngzöl, Révay 1983). In Lithuanian specimens L. uniinflata sporulated abundantly after incubating submerged leaves for several days in Petri dishes under a thin layer of distilled water. Probably the fungus is not genuinely waterborne, but amphibious and is likely to be cosmopolitan in its distribution.

Dwayaangam cornuta Descals, Trans. Br. Mycol. Soc. 1982, 78 (3): 408 - 411. (Fig. $1 \mathrm{C}$ ).

Mycelium hyaline. Conidiophores semi-micronematous, hyaline, 10-12 x $4 \mu \mathrm{m}$. Conidiogenous cells holoblastic, terminal, determinate. Conidia hyaline, 40-75 x 30-50 $\mu \mathrm{m}$, composed from main axis of 1-4 cells, 10-30 x 4-6 $\mu \mathrm{m}$ and four branches of 1-4-5 cells, in pairs, (17) 23-35 x 4.5-6.5 $\mu \mathrm{m}$.

MATERIAL EXAMINED: on decaying wood of Acer platanoides L., moist forest litter, Vilnius environs, Verkiai Regional Park, November 4, 1999; on decaying wood of Quercus robur, moist forest litter, Kèdainiai distr., Juodkiškiai forest, October 3, 2001; from foam, Trakai distr., Jagelonys forest, forest stream, November 14, 2004.

Note: Descals described this species as aquatic after incubating a piece of wood (observed specimen was collected in streamlet in U.K.) under the thin layer of water (Descals, Webster 1982), but earlier in U. K. conidia of this fungus were frequently observed in foam as unidentified (In gold 1942,1959, 1975). In Lithuania this species was collected twice from moist forest litter on decaying wood and once from foam, thus it could be characterised as amphibious. Probably it is widely distributed in the temperate zone of Northern Hemisphere.

Pyramidospora herculiformis N. Singh, Trans. Br. Mycol. Soc. 1976, 66 (2): 347 350. (Fig. $1 \mathrm{D})$.

Mycelium hyaline. Conidiophores semi-macronematous, simple, 20-25 $\mu \mathrm{m}$ long, conidiogenous cells holoblastic, terminal, determinate. Conidia are H-shaped, composed from main axis with 2 cells and four lateral branches of 2-3 (4) cells, 20-25 x 6-8 $\mu \mathrm{m}$ in length.

MATERIAL EXAMINED: on submerged leaves of Corylus avellana L., Varèna distr., Merkinè environs, Dzūkija National Park, Strauja Geomorphologic Reserve, River Strauja, November 1, 1997; on submerged leaves of Corylus avellana L., Kèdainiai distr., Barupè Hydrological Reserve, River Barupé, September 21, 1999; on fallen leaves of Coryllus avellana, moist forest litter, Kèdainiai distr., Stebuliai forest, May 6, 1999.

NotE: This species was described by Singh (1976) as an aquatic hyphomycete collected on submerged rotting leaves of unidentified dicotyledonous plants from Africa (Sierra Leone). In Lithuania this fungus was collected on both submerged leaves of Corylus avellana and leaves of the same plant from moist forest litter, thus this species should be ascribed to amphibious fungi. Here it is for the fist time recorded for Europe.

Tetraploa setifera Ágnes Révay, Nova Hedwigia, 1993, 56 (3-4): 480 - 481. (Fig.1 E).

Mycelium pale brown. Conidiogenous cells holoblastic, intercalary, integratet, determinate. Conidia sessile. The body of conidia are dark brown, smooth, com- 


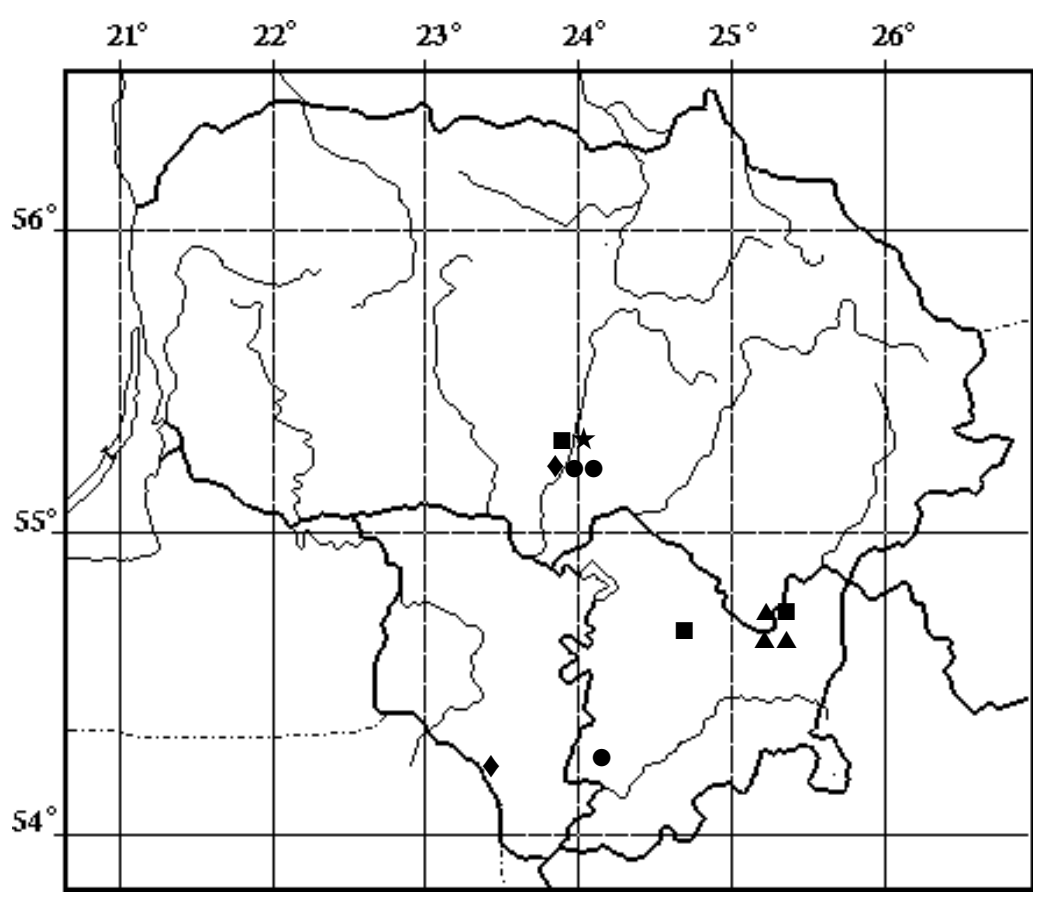

Fig. 2. Localities of Cladorrhinum foecundissimum (\$), Lateriramulosa uni-inflata (४), Dwayaangam cornuta (๘), Pyramidospora herculiformis $(\bullet)$ and Tetraploa setifera $(\star)$ in Lithuania.

posed of four closely developing columns of 4-5 (6) cells, 17-30 x 12-13 $\mu \mathrm{m}$ with appendages. Appendages hyaline, smooth, 3-4 septate, 25-100 x 4-2 $\mu \mathrm{m}$.

MATERIAL EXAMINED: on decaying wood of Fraxinus excelsior L., moist forest litter, Kèdainiai distr., Berunkiškiai forest, October 2, 2002.

Note: Present collection of Tetraploa setifera is the first record of this species from Lithuania and the second record in the world. Originally for the first time this species was described from Hungary on rotten unidentified wood collected near the stream from moist habitat (Révay 1993). Lithuanian specimen morphologically (by shape and size of conidia) is practically identical to the published description of type material. Among six species of genus Tetraploa, only Tetraploa setifera always produce smooth-walled conidia with closely adpressed columns in the apical part. Morphologically $T$. setifera is very close to commonly found on grasses $T$. aristata Berk. \& Br., which in Hungary was also collected on submerged wood of Fagus sylvatica (Révay 1993). Probably future ecological observation might confirm that $T$. aristata and $T$. setifera both belong to group of amphibious fungi. Until present $T$. aristata is known only from Europe.

The fact of record of such rare species as Cladorrhinum foecundissimum, Dwayaangam cornuta, Lateriramulosa uni-inflata, Pyramidospora herculiformis and Tetraploa setifera in different terrestrial and submerged habitats in Lithuania, suggests that distribution and ecology of these fungi is far wider than was reputed. The distribution of above-mentioned species in Lithuania is illustrated in Figure 2. 
Acknowledgements: The author would like to extend a sincere gratitude to the Polish colleagues for kind invitation to contribute to this special issue. Financial support by the Lithuanian State Science and Studies Foundation for the studies is kindly acknowledged.

\section{REFERENCES}

Arx J. A., Ga m s W. 1966. Über Pleurage verruculosa und die zugehörige Cladorrhinum Konidenienform. Nova Hedwigia 13: 199-208.

Bärlocher F. 1992. The Ecology of Aquatic Hyphomycetes. Ecological Studies 94: 1-225.

Borowsk a A. 1986. Flora Polska. Grzyby (Mycota) 16: Grzyby niedoskonałe Deuteromycetes). PWN. Warszawa-Kraków.

Crane J. L. 1968. Freshwater hyphomycetes of the northern Appalachian Highland including New England and three Coastal Plain states. Am. J. Bot. 55: 996-1002.

Descals E., Webster J. 1982. Taxonomic studies on aquatic Hyphomycetes. III. Some new species and a new combinations. Trans. Br. Mycol. Soc. 78 (3): 405-437.

Dix N. J., Webster J. 1995. Fungal Ecology. Chapman \& Hall. London.

Ellis M. B. 1971: Dematiaceous Hyphomycetes. Kew.

Ell is M. B. 1976: More Dematiaceous Hyphomycetes. Kew.

Gönczöl J., Révay Á. 1983. Observations on the Hyphomycetes inhabiting forest litter in Hungary. Acta Bot. Hungarica 29 (1-4): 107-125.

Holobová-J e ch ová V. 1979. Lignicolous and some other saprophytic Hyphomycetes from Hungary. Česká Mykologie 33: 138-149.

Hyde K. D., Goh T.K.1999. Fungi on submerged wood from River Coln, England. Mycol. Res. 103 (12): 1561-1574.

M arva nová L. 1973. Notes on Lateriramulosa uni-inflata. Trans. Br. Mycol. Soc. 60: 145-147.

Matsushim a T. 1971. Microfungi of the Sodomon Islands and Papua-New Guinea. Kobe.

Matsushima T. 1975. Icones microfungorum a Matsushima lectorum. Japan, Shinogi \& CO., LTD, Kobe.

Michaelides J., Kendrick B. 1978. An investigation factors retarding colonization of conifer needles by amphibious hyphomycetes in streams. Mycologia 70: 419-430.

Mouchacca J., Gams W. 1993. The hyphomycete genus Cladorrhinum and its teleomorph connection. Mycotaxon 48: 415-440.

Révay A. 1993. Some new or interesting hyphomycetes from Hungary. Nova Hedwigia 56 (3-4): 473482.

Ingold C. T. 1942. Aquatic hyphomycetes of decaying alder leaves. Trans. Br. Mycol. Soc. 25: 339417.

Ingold C. T. 1959. Submerged aquatic hyphomycetes. Journal of the Quekett microscopical Club 4-5: $115-130$.

Ingold C. T. 1975. An illustrated guide to aquatic and waterborne hyphomycetes (Fungi imperfecti) with notes on their biology. Freshwater Biological Association Scientific Publication 30: 1-96.

Sing h N. 1976. Pyramidospora herculiformis sp. nov., a new aquatic Hyphomycete from Sierra Leone. Trans. Br. Mycol. Soc. 66 (2): 347-350.

\section{Nowe dane o kilku rzadkich na Litwie gatunkach Hyphomycetes}

\section{Streszczenie}

Praca zawiera nowe dane do charakterystyki ekologicznej pięciu gatunków grzybów anamorficznych: Cladorrhinum foecundissimum, Dwayaangam cornuta, Lateriramulosa uniinflata, Pyramidospora herculiformis i Tetraploa setifera. Dyskutowane są ich preferencje co do substratu oraz podane są ich cechy morfologiczne i rozmieszczenie stanowisk poszczególnych gatunków na mapie Litwy. 